\title{
Effects of Anticoccidial Drugs on Gross and Histopathological Lesions Caused by Experimental Rabbit Coccidiosis
}

\author{
Kennedy 0 Ogolla ${ }^{1 *}$, Paul 0 Okumu ${ }^{1}$, Peter K Gathumbi ${ }^{1}$ and Robert M Waruiru ${ }^{1}$ \\ ${ }^{1}$ Department of Veterinary Pathology, Microbiology and Parasitology, University of Nairobi, P.O. Box 29053-00625, Kangemi, Nairobi, \\ Kenya.
}

Received: 8 June, 2018; Accepted: 22 June, 2018; Published: 27 June, 2018

*Corresponding author: Kennedy O. Ogolla, University of Nairobi, PO Box 29053-00625, Kangemi, Nairobi, Kenya, Tel: +254710143604.Email address: kokothogola2008@gmail.com

\begin{abstract}
Effects of commonly used anticoccidial drugs in treating lesions caused by intestinal and hepatic coccidiosis have not been described for anticoccidial-drugs used in Kenya. The objective of this study was to describe the effects of four anticoccidial drugs on gross and histopathological lesions caused by artificially-induced mixed Eimeria infection with inoculant dose of E. flavescens (20\%), E. perforans (21\%), E. intestinalis (9\%), E. coecicola (4.2\%), E. media (11.2\%), E. piriformis (10.6\%), E. stidae (16\%), and E. Magna (8\%). In a controlled laboratory trial, 60 weaner rabbits were randomly allocated to treatment groups A, B, C, D, E and F. Each group had 10 rabbits. Groups A and C served as uninfected-untreated and infecteduntreated control groups, respectively. Groups B, D, E and F were experimentally infected and treated with amprolium, diclazuril, sulfachloropyrazine, and trimethoprim-sulfamethoxazole, respectively. On day 30 post treatment, 3 rabbits from each treatment group were selected randomly and humanely euthanized for gross and microscopic lesion examination. Diclazuril and sulfachloropyrazine treatment groups had significantly minimal to no macroscopic and microscopic lesions. This was consistent with a high efficacy of the drugs in reversing intestinal and hepatic lesions of coccidiosis in rabbits. Rabbits from amprolium, trimethoprim-sulfamethoxazole and infected-untreated control groups presented with severe intestinal and hepatic gross lesions characterized by extensive hepatomegaly, numerous raised hepatic multinodular lesions and marked congestion of the intestines that indicated mild to no effect of the drugs in reversing hepatic and intestinal lesions. Microscopic lesions in rabbits treated with amprolium and trimethoprim-sulfamethoxazole had marked desquamation of intestinal and bile duct epithelium, distended and thickened bile duct, numerous coccidian parasites at different stages of development in duct epithelium and mature oocysts in the intestinal and bile duct lumens; as was in positive control group. Additionally, rabbits from the three treatment groups recorded higher intestinal and hepatic histological lesion scores.
\end{abstract}

Keywords: Amprolium; Diclazuril; macroscopic; pathology; rabbits; Sulfachloropyrazine.

\section{Introduction}

Rabbit coccidiosis is a protozoan infection caused by Eimeria spp. parasites [1]. Two forms of coccidiosis affect rabbits resulting in mild to severe macroscopic (gross) and microscopic (histopathologic) lesions [2]. One form is hepatic coccidiosis caused by Eimeria stiedae that targets the liver resulting in high morbidity and mortality depending on infective dose [1]. The other form is intestinal coccidiosis caused by several Eimeria species which have varied pathogenicity and target sites along the intestinal tract [1]. Most pathogenic of these are E. intestinalis and E. flavescens; E. magna, E. media, E. irresidua, E. perforans, E. piriformis, E. exigua and E. vejdovskyi have moderate to mild pathogenicity [3]. Mixed infection by both forms are common with weaner rabbits being most susceptible to the infection [4, 5]. Transmission of both forms of coccidiosis is mainly by fecaloral route through consumption of feed and water contaminated by sporulated oocysts [6]. Most cases of hepatic coccidiosis present with gross and histological lesions characterized by hepatomegaly, raised multinodular lesions on the liver surface, distended gallbladder, dilated biliary tree, distended bile duct, atrophy of biliary epithelium, hepatocyte necrosis among others [7-14]. Gross and microscopic intestinal lesions of intestinal coccidiosis have been described in numerous studies $[1,11$, $14,15]$. Several anticoccidial drugs are available for preventing and treating these lesions [16]. Diclazuril, a derivative of benzeneacetonitrile, is indicated for prophylactic and curative use in rabbits at $5 \mathrm{ppm}$ and $10 \mathrm{ppm}$, respectively [17]. It acts by blocking the excretion of oocysts which interrupts the life cycle of Eimeria spp. [18]. Similarly, sulphonamides such as sulfadiazine, sulfamethazine, sulfamerazine and sulfaquinoxaline have been used in treatment and prevention of rabbit coccidiosis for decades [19]. Other anticoccidial drugs that have been widely used on clinical coccidiosis under various dosages with varied efficacies include amprolium, salinomycin, maduramycin, monensin, clopidol, narasin, robenidine and lasalocid [16]. Most coccidiostats are rarely effective against coccidiosis once rabbits present with clinical signs [1]. Consequently, they are effective when administered on day of exposure to the oocyst [20]. Majority of coccidiostats inhibit metabolic pathways of merozoites, meronts and sporozoites thus interrupting completion of the life cycle [16]. Efficacious therapeutic anticoccidials are able to either 
ameliorate and/or eliminate these signs and lesions [20, 21]. However, the effectiveness of these anticoccidials in reversing the gross and histological lesions caused by intestinal and hepatic coccidiosis has not been studied in details. Joyner et al. [22] demonstrated how growth, oocyst shed, and serum activities respond to treatments with robenidine, sulphaquinoxaline, clopidol and methyl benzoquate. Additionally, Peeters et al. described activities of robenidine, salinomycin, and clopidolmethylbenzoate combination against rabbit hepatic coccidiosis [23]. The aim of the present study was to describe the effects of amprolium, trimethoprim-sulfamethoxazole, sulfachloropyrazine and diclazuril in reversing (resolving) the macroscopic and microscopic lesions caused by experimentally-induced rabbit coccidiosis

\section{Materials and Methods}

\section{Design of Experiment}

A total of 60 weanling California white and New Zealand white rabbit breeds were randomly allocated to treatment groups A, B, C, D, E and F each consisting of 10 rabbits. Groups A and $C$ served as negative (not infected and not treated) and positive (infected but not treated) controls, respectively. Rabbits in groups B, C, D, E and F were experimentally infected with 120,000 mixed sporulated oocysts of E. perforans (21\%), E. flavescens $(20 \%)$ E. intestinalis (9\%), E. coecicola (4.2\%), E. media (11.2\%), E. piriformis (10.6\%), E. stidae (16\%), and E. Magna (8\%) prepared as described by Ryley et al. [24]. The inoculant was administered orally using a syringe. Rabbits were then treated when oocyst counts per gram of feces reached 500,000 o.p.g and/or when clinical signs of coccidiosis were observed. Group B was treated with amprolium administered at 1000ppm for 7 consecutive days. Group D was treated with diclazuril (Diclosol 1\%) at $10 \mathrm{ppm}$ for 48 hours. Group E was treated with sulfachloropyrazine for six days as follows: $1^{\text {st }}, 2^{\text {nd }}, 3^{\text {rd }}, 5^{\text {th }}, 7^{\text {th }}$, and $9^{\text {th }}$ at $2000 p p m$. Group F was treated with trimethoprim-sulfamethoxazole combination administered at $1000 \mathrm{ppm}$ for 7 consecutive days. All drugs were administered in drinking water. The rabbits were clinically observed on a daily basis for 20 days after treatment. On day 20 post treatment, three rabbits were randomly selected from each treatment group for necropsy. The rabbits were euthanized by sodium pentobarbital (Euthatol $\AA$ ) at $100 \mathrm{mg} / \mathrm{kg}$ via intracardiac route and systemic necropsy performed according to the guidelines provided by the University of Nairobi.

\section{Gross and Histopathological Examination}

Gross lesions were examined at autopsy and tissue samples collected from the liver, duodenum, ileum, caecum and colon for microscopic examination, and lesion scoring. Histopathology samples were preserved in buffered formalin (10\%) and routinely processed [25]. Thin sections 4-5 $\mu \mathrm{m}$ were prepared and stained using haematoxylin and eosin [26]. All the slides were examined using a light microscope and lesion comparisons made in treatment groups. Histopathological lesions were scored according to a set criteria: marked (41-100\% of tissue involved), moderate $(21-40 \%$ of tissue involved), mild (11-20\% of tissue involved) and minimal ( $0-10 \%$ of tissue involved) by recording the nature and extent of lesion and its frequency of occurrence in randomly selected sites in the tissue [27]. Specific intestinal and hepatic lesions scored at various magnification powers are as shown in Table 1.

Table 1: Lesion scoring criteria used and specific liver and intestinal lesions scored in the experimental efficacy trial.

\begin{tabular}{|c|c|c|c|c|c|c|}
\hline \multirow[b]{2}{*}{$\begin{array}{c}\text { Grade/ } \\
\text { Score }\end{array}$} & \multirow[b]{2}{*}{$\begin{array}{c}\text { Grade } \\
\text { description }\end{array}$} & \multicolumn{3}{|c|}{ Focal and multifocal lesions } & \multicolumn{2}{|c|}{ diffusely distributed lesions } \\
\hline & & $\begin{array}{c}\text { various Eimeria stages } \\
\text { in lamina propia and } \\
\text { enterocyte (X400 mag) } \\
\text { (10 sites examined) }\end{array}$ & $\begin{array}{c}\text { various Eimeria } \\
\text { stages in liver ducts } \\
\text { (X400 mag) } \\
\text { (10 sites examined) }\end{array}$ & $\begin{array}{l}\text { Multifocal lesions } \\
\text { coalescing in liver } \\
\text { architecture } \\
\text { (X40 mag) } \\
\text { (5 sites } \\
\text { examined) }\end{array}$ & $\begin{array}{c}\text { Desquamated } \\
\text { epithelium/ } \\
\text { Enterocytes } \\
\text { (X400) } \\
\text { (10 sites examined) }\end{array}$ & $\begin{array}{l}\text { Desquamated } \\
\text { duct epithelium } \\
\text { (X400 mag) } \\
\text { (10 sites } \\
\text { examined) }\end{array}$ \\
\hline 1 & Minimal & $<10 \%$ of tissue involved & $\begin{array}{c}<10 \% \text { of tissue } \\
\text { involved }\end{array}$ & $\begin{array}{c}<10 \% \text { of the tissue } \\
\text { is involved }\end{array}$ & $\begin{array}{l}<10 \% \text { of tissue is } \\
\text { involved }\end{array}$ & $\begin{array}{l}<10 \% \text { of tissue is } \\
\text { involved }\end{array}$ \\
\hline 2 & Mild & $\begin{array}{l}11-20 \% \text { of the tissue } \\
\text { involved }\end{array}$ & $\begin{array}{l}11-20 \% \text { of the tissue } \\
\text { involved }\end{array}$ & $\begin{array}{l}11-20 \% \text { of tissue } \\
\text { involved }\end{array}$ & $\begin{array}{l}11-20 \% \text { of tissue } \\
\text { involved }\end{array}$ & $\begin{array}{l}11-20 \% \text { of tissue } \\
\text { involved }\end{array}$ \\
\hline 3 & Moderate & $\begin{array}{l}\text { Between } 21 \text { to } 40 \% \text { of } \\
\text { tissue parts affected }\end{array}$ & $\begin{array}{l}\text { Between } 1 \text { to } 40 \% \text { of } \\
\text { tissue parts affected }\end{array}$ & $\begin{array}{c}\text { Between } 21 \text { to } \\
40 \% \text { of tissue parts } \\
\text { affected }\end{array}$ & $\begin{array}{l}\text { Between } 21 \text { to } 40 \% \text { of } \\
\text { tissue parts affected }\end{array}$ & $\begin{array}{c}\text { Between } 21 \text { to } \\
40 \% \text { of tissue parts } \\
\text { affected }\end{array}$ \\
\hline 4 & Marked & $\begin{array}{c}\text { Between } 41 \text { to } 100 \% \text { of } \\
\text { tissue parts affected }\end{array}$ & $\begin{array}{c}\text { Between } 41 \text { to } \\
\text { 100\% of tissue parts } \\
\text { affected }\end{array}$ & $\begin{array}{l}\text { Between } 41 \text { to } \\
100 \% \text { of tissue } \\
\text { parts affected }\end{array}$ & $\begin{array}{l}41-100 \% \text { of tissue } \\
\text { section involved }\end{array}$ & $\begin{array}{l}41-100 \% \text { of tissue } \\
\text { section involved }\end{array}$ \\
\hline
\end{tabular}




\section{Animal Welfare}

Rabbits were housed in clean cages in a room with uniform environmental quality and fed on coccidia-free commercial pellets. Water was provided to the rabbits ad libitum. The experiment was approved by the University of Nairobi Ethics and Animal Use Committee.

\section{Data Analysis}

Data obtained from the study was entered in MS excel 2016 spreadsheet. One or two way ANOVA of Genstat was used to perform analysis of variance. Significant differences of means of different treatment groups were illustrated by Bonferroni multiple comparison test to control overall significance levels as described in Genstat statistical analysis program (GenStat 15th Edition). Means, Standard Error of Means (SEM) and significance difference at 0.05 were provided.

\section{Results}

\section{External Examination and Macroscopic (Gross) Findings}

From external examination, most of the rabbit carcasses from amprolium, trimethoprim-sulfamethoxazole and infecteduntreated positive control groups had rough hair coats, matted perineal area, appeared 'pot-bellied', were emaciated and dehydrated (Figure 1). Icteric mucous membrane was seen in two rabbits from positive control and amprolium treatment groups. However, few rabbits from these treatment groups did not present with any overt gross finding at external examination. One rabbit carcass from sulfachloropyrazine group had rough hair coat with slight dehydration but the rest from the group and those from diclazuril treatment group had no significant findings at external examination. Rabbits from amprolium (B), trimethoprim-sulfamethoxazole (F) and infected-untreated (C) treatment groups presented with severe hepatic and intestinal gross lesions at necropsy. Intestines from these three treatment groups presented the following lesions: severe congestion of the duodenum, ileum and caecum (Figures 2 and 3); dark-gray

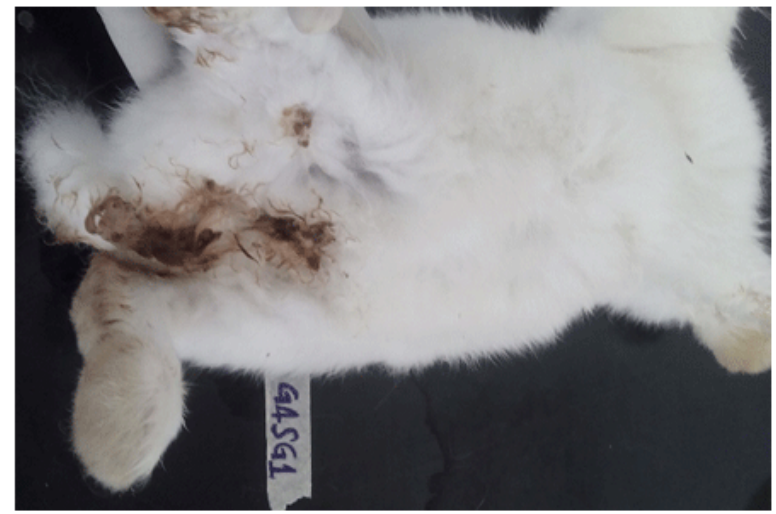

Figure 1: A rabbit allocated to the diclazuril treatment group (D) with diarrhea (matted perineal area), rough hair coat and distended abdomen (pot-belly) on day 1 of treatment. semi-solid luminal content (Figure 4), some with blood stains and dark-necrotic foci on the caecum (Figure 2). Some sections of the intestines had hyperemia and echymotic hemorrhages on the serosal surface. Ballooned sections of the caecum (BC) and ileum were also observed (Figure 2). Intestinal mucosa of duodenum, jejunum and ileum was discoloured with numerous hemorrhagic spots. Intestines from diclazuril (D) and sulfachloropyrazine (E) treatment groups had minimal to no gross lesions (Figure 5), with most appearing similar to intestines from uninfected-untreated control group (A). Treatments by amprolium and trimethoprimsulfamethoxazole drugs were ineffective in reversing the gross lesions caused by hepatic coccidiosis. Livers from amprolium and trimethoprim-sulfamethoxazole treatment groups had lesions indistinguishable from those manifested by infected but not treated control group. These lesions included discoloured and enlarged livers with markedly dilated bile ducts and gallbladder that contained thick yellowish-white contents that was viscous to solid in consistency (Figures 6, 7 and 8). The entire biliary tree was distended with yellowish-white thick-flowing content (Figures 7 and 8). Livers from treatment groups B, C and F had clearlydemarcated raised yellowish-white nodular lesions $(0.5-1 \mathrm{~cm}$ in diameter) covering the entire liver surface (Figure 6). Some of these multinodular lesions occasionally coalesced to form larger linear nodules (Figure 6). Additionally, these livers had fibrinous exudates on their surfaces (Figure 6), were firm in consistency and were congested. Wet smears of the intestinal mucosa and livers revealed both mature and immature eimerian instead of eimerian stages. Livers from sulfachloropyrazine treatment group were only slightly enlarged with few tiny yellowish-white lesions on the surface which were for most cases not raised. The gallbladders from sulfachloropyrazine treatment group were slightly distended with greenish-yellow slightly viscous content (Figure 8E) indicating satisfactory efficacy of sulfachloropyrazine in reversing these lesions, close to the free-flowing contents of the negative control and diclazuril treatment group which had superior efficacy in this trial (Figure 8D). Livers from diclazuril treatment group had no significant lesions and were the same in size with those from uninfected-untreated control group (Figure 4).

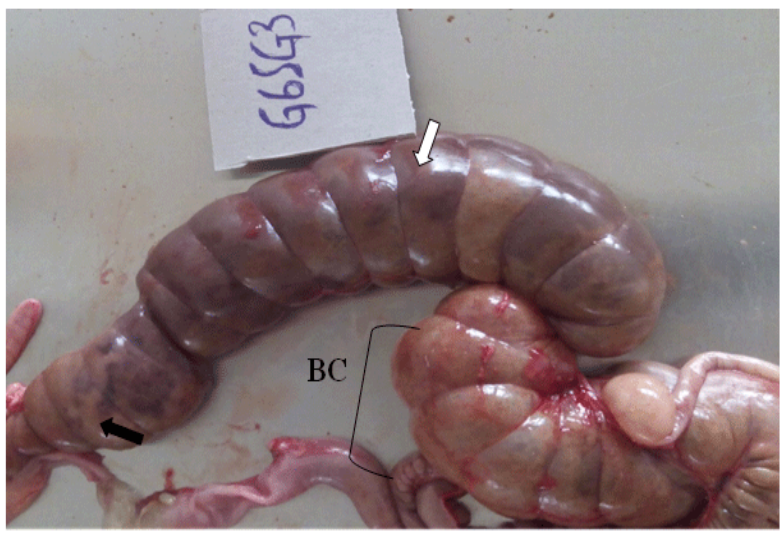

Figure 2: Gross intestinal lesions from trimethoprim-sulfamethoxazole treatment group (F) showing marked congestion and hyperemia (white arrow), necrotic caecal parts (black arrow) and ballooned section of the caecum (BC) 


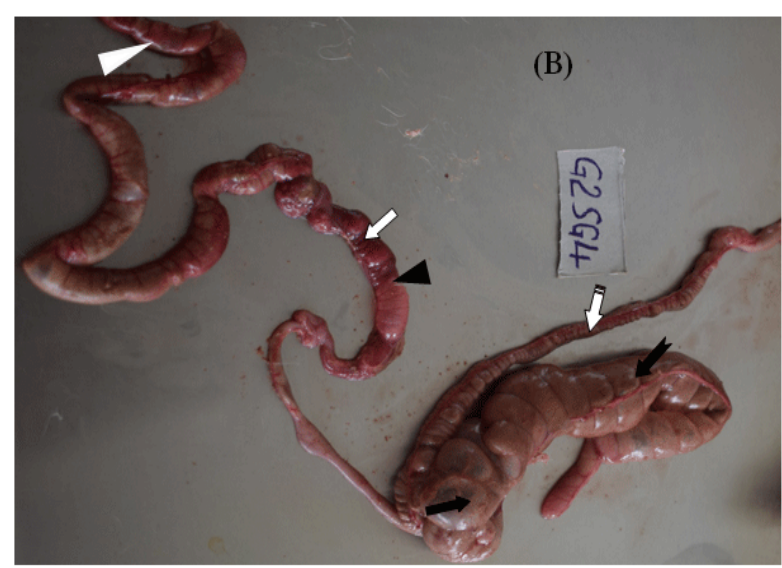

Figure 3: Amprolium treatment group (B) showing ballooned section of the ileum (black arrow head) and caecum (black arrow), extensive congestion and hyperemia of the ileum (white arrow), jejunum (white arrow head) colon (white arrow with broken ends) caecum (black arrow with curved end).

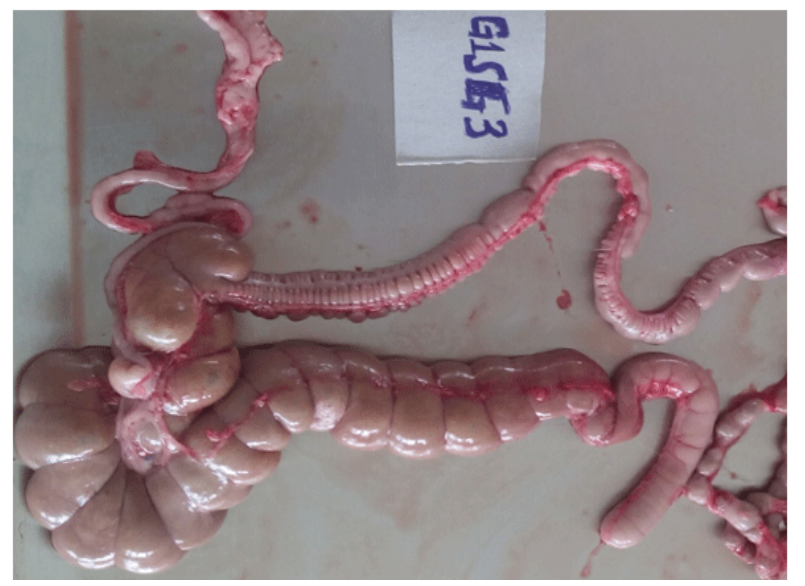

Figure 5: Gross intestinal lesions, a shiny, healthy pink caecum and colon from negative control group

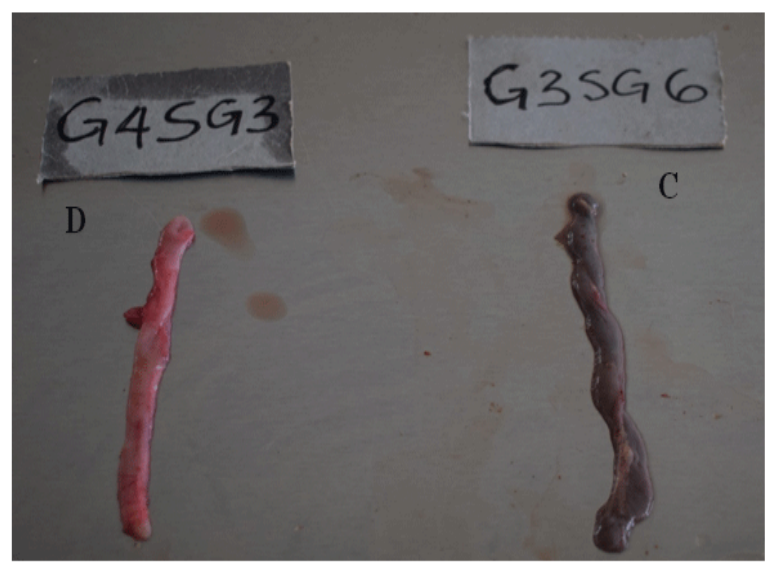

Figure 4: Gross intestinal lesions: D- duodenal section from diclazuril treatment group with the normative pink colour compared with the highly congested and necrotic duodenal part containing dark luminal content from the positive control group (C)

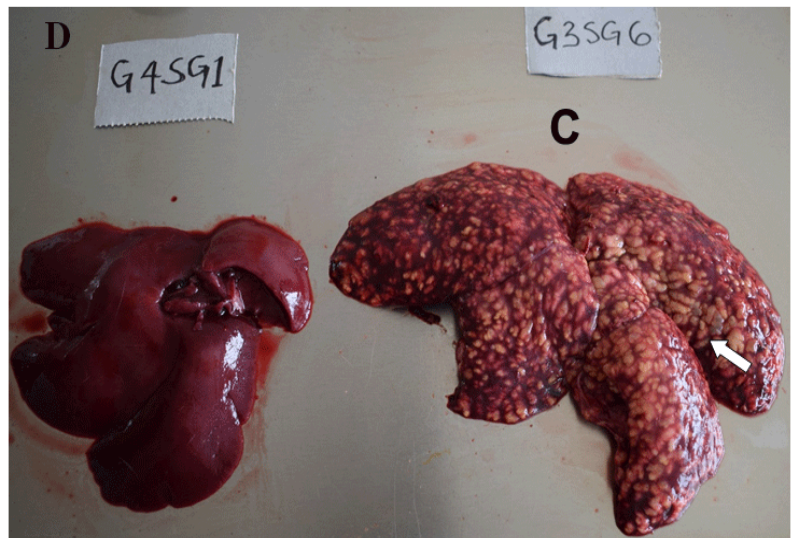

Figure 6: Rabbit livers from diclazuril (D) and positive control (C) treatment groups. Normal liver from diclazuril treatment group and one with marked hepatomegaly, coalesced nodular lesions (arrow) and fibrinous strands on liver surface from infected but not treated group (C) at the end of experiment

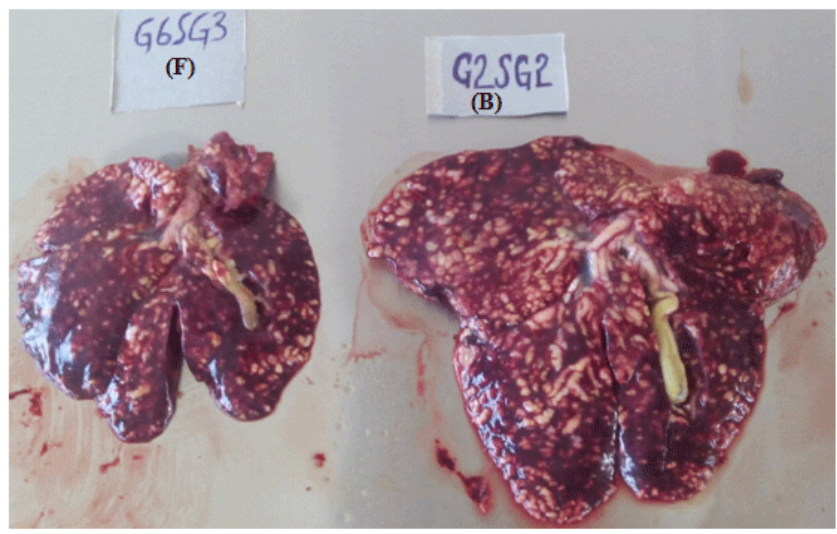

Figure 7: Livers from trimethoprim-sulfamehtoxazole (F) and amprolium (B) treatment groups. Livers from amprolium treatment group had more extensive hepatomegally compared to those from trimethoprim-sulfamethoxazole treatment groups though the extent of hepatic injury was severe in both groups. 

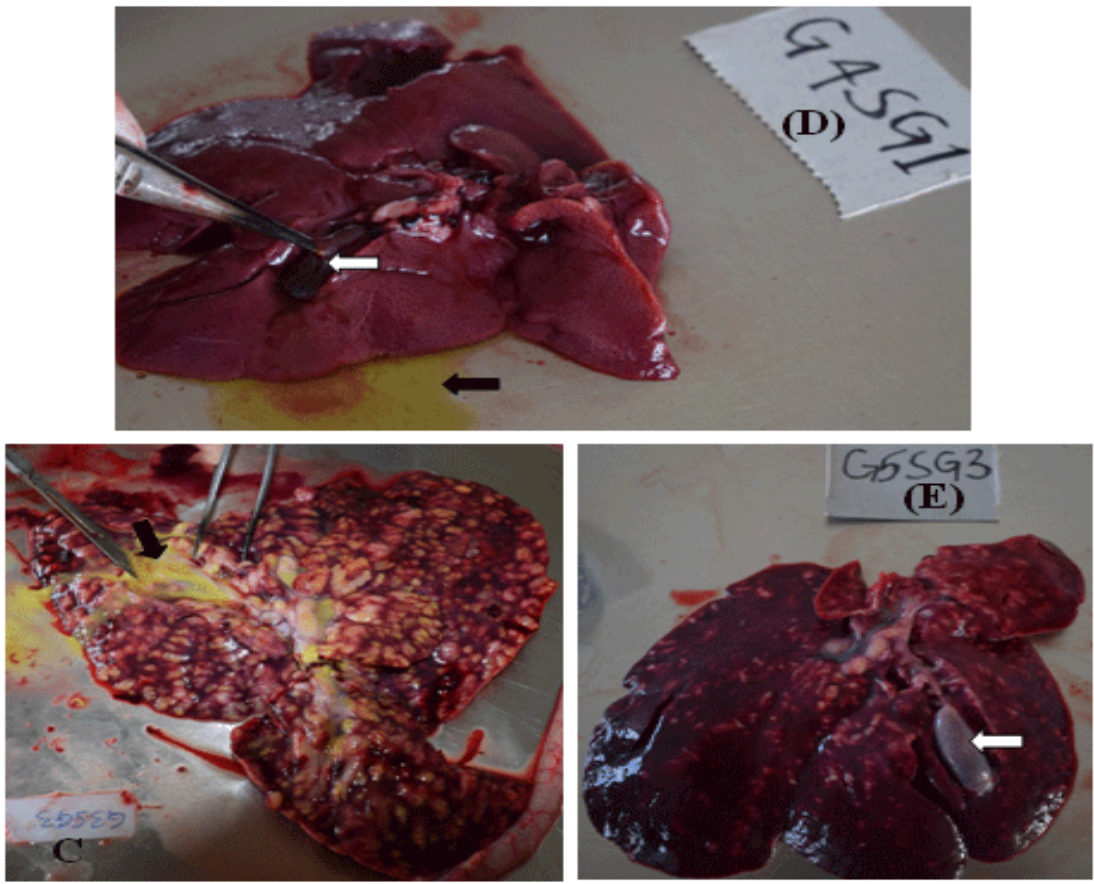

Figure 8: Hepatic lesions at the end of the efficacy trial: D, greenish-yellow contents from a normative gallbladder from diclazuril treatment group (black arrow), and gallbladder and liver parenchyma with the normal dark appearance (white arrow). C, thick whitish-yellow contents from incised gallbladder with numerous multinodular lesions from infected untreated group. E, slightly distended gallbladder dark appearance and fading liver lesions from sulfachloropyrazine treatment group.

\section{Histopathologic (Microscopic) Lesions and Mean Lesion Scores}

Histological examination of the intestines revealed severe desquamation of epithelium (Figure 9A), extensive atrophy of villi lining (enterocytes of villi epithelium) (Figure 9B), marked hyperplasia of the submucosal goblet cells (Figures 9C and 9D) and immature developmental stages of Eimeria spp. parasites within enterocytes (Figures 9E and 9F) in treatment groups B, C, E and F. Severe microscopic hepatic and intestinal lesions scores were recorded by amprolium(B), trimethoprimsulfamethoxazole(F) and infected-untreated(C) treatment groups. Mean lesion scores are presented in Table 1 (intestinal) and 2 (hepatic). Other lesions observed less frequently but not scored were congestion, capillary haemorrhages and dilation of blood vessels, red blood cells within the lumen of the intestines, fusion of the villi, precipitates of protein in the intestinal lumen, oedema of the muscularis and necrosis of enterocytes.

Hepatic lesions were characterized by marked fibrosis and hyperplasia of the peribiliary (periductal) parts (Figures 10A \& 10B) with leucocytic cell infiltration around the bile ducts (Figure $10 \mathrm{E}$ ), formation of new ductules around the ducts (Figure 10D), severe distention of the bile duct accompanied by flattening and desquamation of their duct epithelium (Figure 10C), hyperplasia of remaining biliary epithelium with varied developmental stages of Eimeria (thin walled ovoid oocysts, macrogametocytes and microgametocytes) within biliary epithelium (Figures 10D, $10 \mathrm{E}$ and $10 \mathrm{~F}$ ), atrophy and necrotic degenerative changes of the hepatocytes and multiple coalescing lesions in treatment groups $\mathrm{B}, \mathrm{C}$ and $\mathrm{F}$ as presented in Figure 10. The enlarged bile ducts were lined by pronounced columnar epithelial cells that formed several papillary fronds which extended to the lumen of the duct (Figure 11A). There were areas with oocysts granulomas (Figure 11B). Bile ducts lumen were filled and distended with almost mature stages of Eimeria oocyst which resulted in pressure atrophy on the neighbouring hepatocytes (Figure 11E). These lesions were severe in treatment groups B, C and F with only few seen in treatment group $\mathrm{E}$, fewer in $\mathrm{D}$ but absent in the negative control group (A). Liver lesions that were less frequently observed were congested and dilated blood vessels (Figure 11B), haemorrhages and bile pigmentation in the liver parenchyma (Figure $11 \mathrm{C}$ and 11D), and precipitation of protein in the duct lumen. Livers from diclazuril treatment group had no significant lesions (Figure 11F). Mean lesion scores are summarized in Table 3.

\section{Discussion}

In this study, diclazuril and sulfachloropyrazine (sulphonamide) were efficacious in reducing gross and histopathology lesions of rabbit coccidiosis. Samples from rabbits treated with the two drugs recorded low to no histopathological lesion scores close to those recorded by negative control group (Tables 2 and 3). On the other hand, amprolium and trimethoprimsulfamethoxazole treatment groups recorded poor efficacy against lesions from rabbit coccidiosis. No significant difference $(p>0.05)$ was seen between gross and microscopic lesion scores recorded by samples from rabbits under amprolium and trimethoprim- 

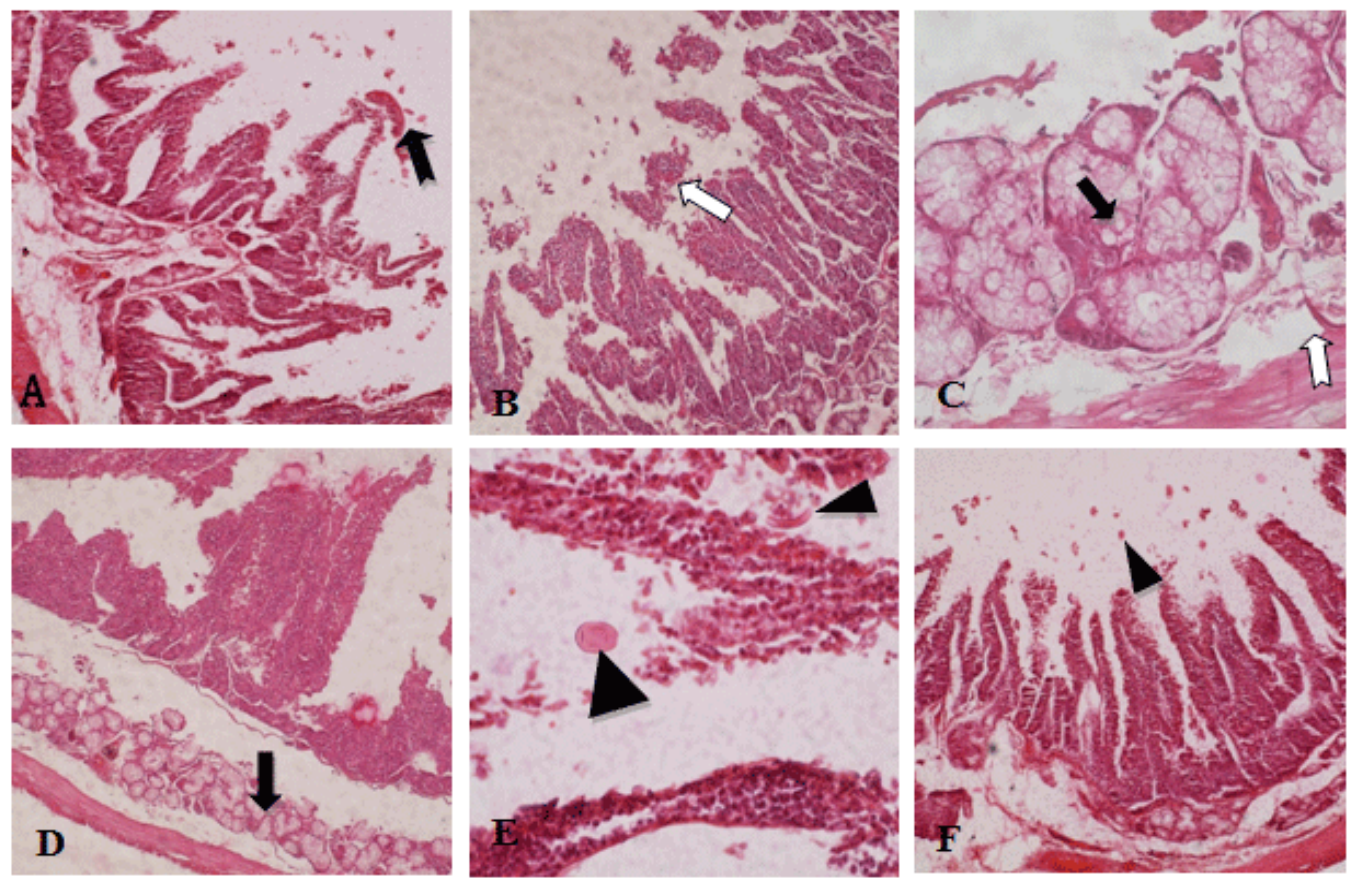

Figure 9: Microscopic characteristics of the intestinal lesions-Hematoxylin and Eosin stain. A, desquamated intestinal epithelium. B, disintegration of intestinal mucosa x400 (amprolium group). C, hyperplasia of goblet cells x400 (trimethoprim-sulfamethoxazole group). D, hyperplasia of goblet cells within the submucosa $\mathrm{x} 40$. E, oocysts within the intestinal lumen $\mathrm{x} 400$. F, several oocysts within the intestinal lumen $\mathrm{x} 40$.

Table 2: Mean intestinal microscopic lesion scores quantifying the effects of the anticoccidials on coccidial lesions.

\begin{tabular}{|c|c|c|c|c|c|c|}
\hline Treatment group & $\begin{array}{c}\text { Caeco-colon } \\
\text { lesion scores }\end{array}$ & \multicolumn{2}{|c|}{ Duodenal lesion scores } & \multicolumn{3}{|c|}{ Jejunum-ileum lesion scores } \\
\hline & $\begin{array}{c}\text { Epithelial } \\
\text { desquamation }\end{array}$ & $\begin{array}{c}\text { Eimeria stages in } \\
\text { intestinal tissue and } \\
\text { lumen }\end{array}$ & $\begin{array}{c}\text { Epithelial } \\
\text { desquamation }\end{array}$ & $\begin{array}{c}\text { Eimeria spp. stages in } \\
\text { intestinal tissue and } \\
\text { lumen }\end{array}$ & $\begin{array}{c}\text { Epithelial } \\
\text { desquamation }\end{array}$ & $\begin{array}{c}\text { Eimeria stages in } \\
\text { intestinal tissue } \\
\text { and lumen }\end{array}$ \\
\hline Negative control (A) & $1.33 \pm 0.33^{\mathrm{a}}$ & $1.00 \pm 0.00^{\mathrm{a}}$ & $2.33 \pm 0.67^{\mathrm{ab}}$ & $1.00 \pm 0.00^{\mathrm{a}}$ & $3.0 \pm 0.00^{\mathrm{a}}$ & $1.00 \pm 0.00^{\mathrm{a}}$ \\
\hline Amprolium (B) & $3.67 \pm 0.33^{\mathrm{bc}}$ & $3.67 \pm 0.33^{\mathrm{b}}$ & $4.00 \pm 0.00^{\mathrm{b}}$ & $4.00 \pm 0.00^{\mathrm{b}}$ & $4.00 \pm 0.00^{\mathrm{b}}$ & $4.00 \pm 0.00^{\mathrm{b}}$ \\
\hline Positivecontrol (C) & $4.00 \pm 0.00^{\mathrm{c}}$ & $4.00 \pm 0.00^{\mathrm{b}}$ & $3.67 \pm 0.33^{\mathrm{b}}$ & $4.00 \pm 0.00^{\mathrm{b}}$ & $4.00 \pm 0.00^{\mathrm{b}}$ & $4.00 \pm 0.00^{\mathrm{b}}$ \\
\hline Diclazuril (D) & $1.67 \pm 0.67^{\mathrm{ab}}$ & $1.00 \pm .00^{\mathrm{a}}$ & $1.67 \pm 0.33^{\mathrm{a}}$ & $1.00 \pm 0.00^{\mathrm{a}}$ & $2.67 \pm 0.33^{\mathrm{a}}$ & $1.00 \pm 0.00^{\mathrm{a}}$ \\
\hline $\begin{array}{c}\text { Sulfachloropyrazine } \\
\text { (E) }\end{array}$ & $3.00 \pm 0.58 \mathrm{a}^{\mathrm{bc}}$ & $3.00 \pm 0.58^{\mathrm{b}}$ & $3.00 \pm 0.00^{\mathrm{ab}}$ & $3.33 \pm 0.33^{\mathrm{b}}$ & $3.00 \pm 0.00^{\mathrm{a}}$ & $2.33 \pm 0.88^{\mathrm{ab}}$ \\
\hline $\begin{array}{c}\text { Trimethoprim- } \\
\text { sulfamethoxazole (F) }\end{array}$ & $4.00 \pm 0.00^{\mathrm{c}}$ & $4.00 \pm 0.00^{\mathrm{b}}$ & $4.00 \pm 0.00^{\mathrm{b}}$ & $4.00 \pm 0.00^{\mathrm{b}}$ & $4.00 \pm 0.00^{\mathrm{b}}$ & $4.00 \pm 0.00^{\mathrm{b}}$ \\
\hline P value & 0.001 & $<0.001$ & 0.001 & $<0.001$ & $<0.001$ & $<0.001$ \\
\hline
\end{tabular}

Aggregated mean lesion scores of three rabbits per treatment group. Values without similar superscript in a column are significantly different at 0.05 
Table 3: Mean hepatic microscopic lesion scores quantifying the effects of the anticoccidials on coccidial lesions.

\begin{tabular}{|c|c|c|c|c|c|c|}
\hline \multirow[b]{2}{*}{ Treatment group } & \multicolumn{6}{|c|}{ Hepatic Lesion Scores } \\
\hline & $\begin{array}{c}\text { Epithelial } \\
\text { desquamation }\end{array}$ & $\begin{array}{c}\text { Duct } \\
\text { distension }\end{array}$ & $\begin{array}{l}\text { Eimeria spp. stages } \\
\text { in liver tissues }\end{array}$ & $\begin{array}{l}\text { Hepatocyte } \\
\text { necrosis }\end{array}$ & $\begin{array}{c}\text { Periductal/ } \\
\text { peribiliary fibrosis }\end{array}$ & $\begin{array}{c}\text { Multiple } \\
\text { coalescing lesions }\end{array}$ \\
\hline Negative control (A) & $1.33 \pm 0.33^{\mathrm{a}}$ & $1.67 \pm 0.33^{\mathrm{a}}$ & $1.00 \pm 0.00^{\mathrm{a}}$ & $1.00 \pm 0.00^{\mathrm{a}}$ & $1.00 \pm 0.00$ & $1.00 \pm 0.00^{\mathrm{a}}$ \\
\hline Amprolium (B) & $4.00 \pm 0.00^{\mathrm{b}}$ & $4.00 \pm 0.00^{\mathrm{b}}$ & $4.00 \pm 0.00^{\mathrm{b}}$ & $4.00 \pm 0.00^{c}$ & $4.00 \pm 0.00$ & $4.00 \pm 0.00^{\mathrm{b}}$ \\
\hline Positive control (C) & $4.00 \pm 0.00^{\mathrm{b}}$ & $4.00 \pm 0.00^{\mathrm{b}}$ & $4.00 \pm 0.00^{\mathrm{b}}$ & $4.00 \pm 0.00^{c}$ & $4.00 \pm 0.00$ & $3.67 \pm 0.33^{b}$ \\
\hline Diclazuril (D) & $1.00 \pm 0.00^{\mathrm{a}}$ & $1.33 \pm 0.33^{\mathrm{a}}$ & $1.00 \pm 0.00^{\mathrm{a}}$ & $1.00 \pm 0.00^{\mathrm{a}}$ & $1.00 \pm 0.00$ & $1.00 \pm 0.00^{\mathrm{a}}$ \\
\hline Sulfachloropyrazine (E) & $3.33 \pm 0.67^{b}$ & $2.33 \pm 0.33^{\mathrm{a}}$ & $3.67 \pm 0.33^{b}$ & $2.67 \pm 0.33^{\mathrm{b}}$ & $2.00 \pm 0.00$ & $1.67 \pm 0.33^{\mathrm{a}}$ \\
\hline $\begin{array}{c}\text { Trimethoprim- } \\
\text { sulfamethoxazole (F) }\end{array}$ & $4.00 \pm 0.00^{\mathrm{b}}$ & $4.00 \pm 0.00^{\mathrm{b}}$ & $4.00 \pm 0.00^{\mathrm{b}}$ & $4.00 \pm 0.00^{c}$ & $4.00 \pm 0.00$ & $4.00 \pm 0.00^{\mathrm{b}}$ \\
\hline Pvalue & $<0.001$ & $<0.001$ & $<0.001$ & $<0.001$ & - & $<0.001$ \\
\hline
\end{tabular}

Values without similar superscript in a column are significantly different at 0.05 . Aggregated mean lesion scores of three rabbits per treatment group. 

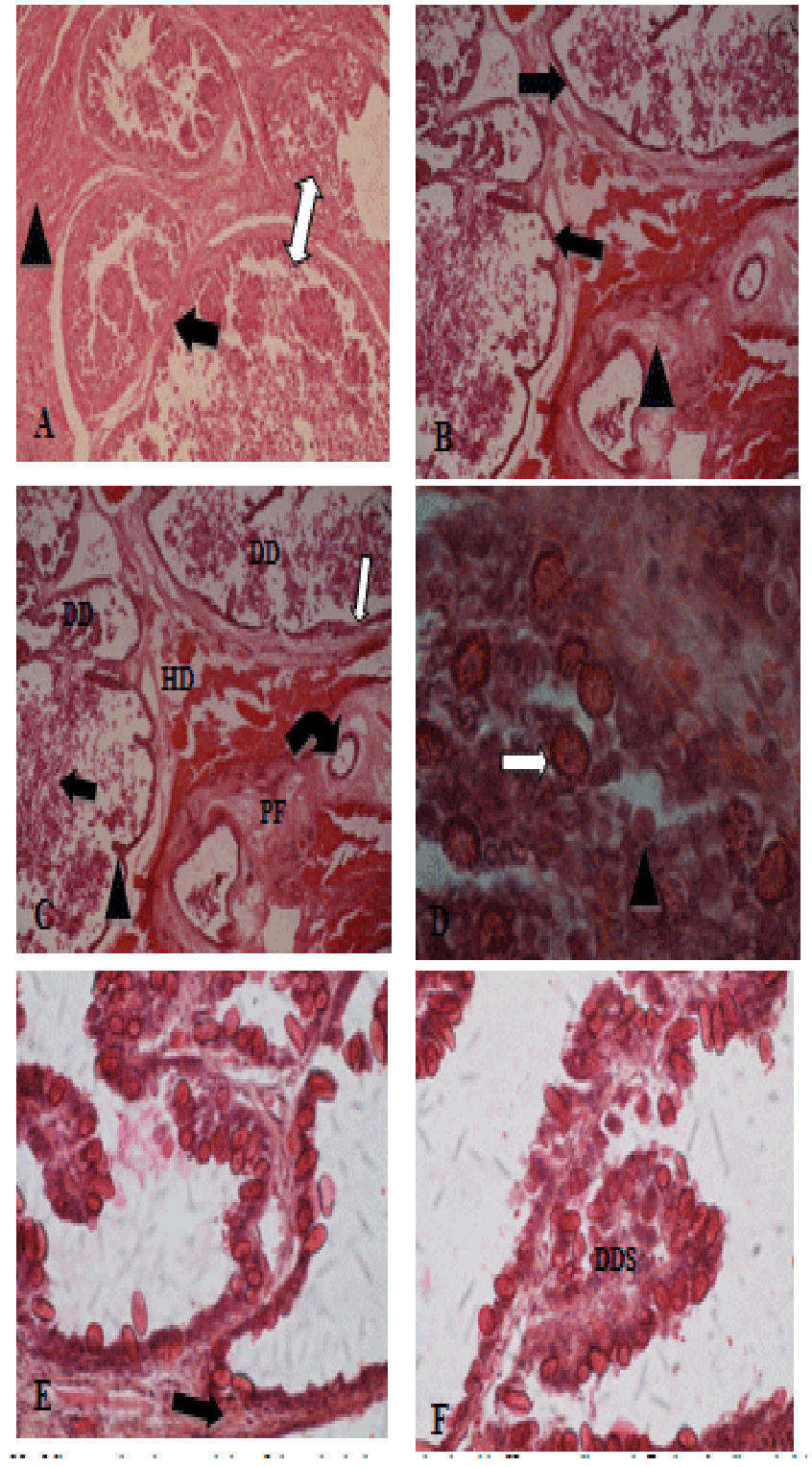

Figure 10: A Microscopic characteristic of hepatic lesions stained with Hematoxylin and Eosin. A, distended bile duct containing numerous oocysts in the lumen (Double-headed white arrow), marked periductal (peribiliary) fibrosis (Black arrow head) and desquamated duct epithelium (arrow) x40 from a rabbit treated with amprolium. B, Severe desquamation of duct epithelium (Arrow), and periductal fibrosis (arrow head) x100 in an infected-untreated rabbit. C, Distended ducts (DD) having flattened epithelium with minimal (arrow head) to no projections into the lumen (white arrow) filled with oocysts (black arrow), peribiliary fibrosis (PF), formation of new ductules (Bent arrow) and an area of hepatocyte necrosis and degeneration (HD) x100 in a rabbit from trimethoprim-sulfamethoxazole group. D, oval to circular large macrogametocytes within duct epithelium (White arrow), a round small microgametocyte (arrow head) at x1000 in a rabbit from amprolium treatment group. E, Different developmental stages of Eimeria within the duct epithelium with infiltration of inflammatory cells (Arrow) x400 in a rabbit from amprolium group. F, different developmental stages of Eimeria with varied shapes and sizes (DDS) $\mathrm{x} 400$ from trimethoprimsulfamethoxazole treatment.
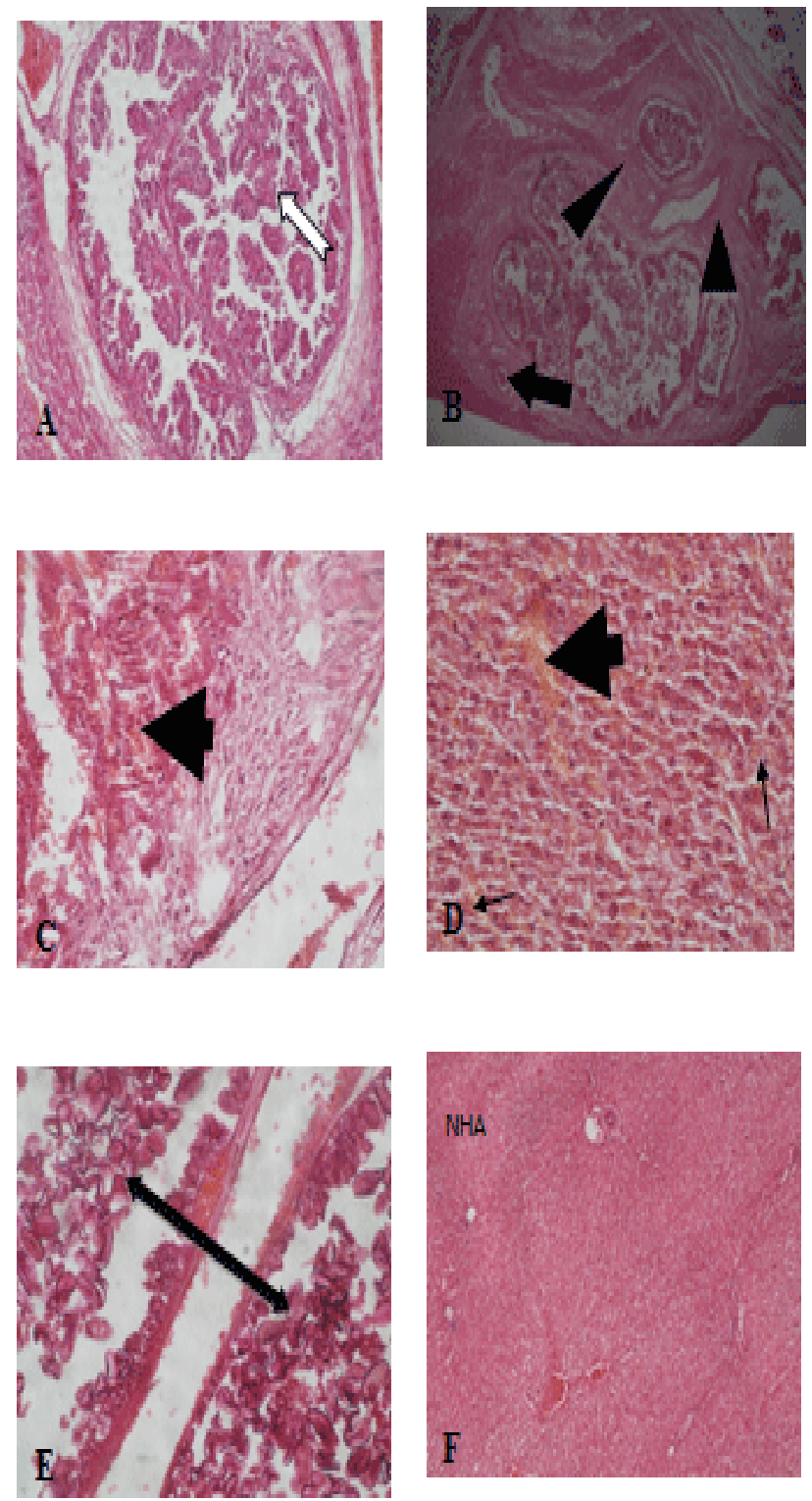

Figure 11: Microscopic hepatic lesions stained with Hematoxylin and Eosin. A, Numerous papillary branches in the bile duct arising from extensive proliferation of columnar epithelial cells of the biriary system x 40 (White arrow) in a rabbit from trimethoprim-sulfamethoxazole group. B, Congestion (arrow), peribiliary fibrosis (arrow heads) x100 in rabbit from sulfachloropyrazine group. C, bile pigmentation x400 (black arrow) (trimethoprim-sulfamethoxazole group). D, bile pigmentation within the hepatic parenchyma (thick arrow) and yellowish-brown foci of necrosis (thin arrow) at $\mathrm{x} 400$ from trimethoprim-sulfamethoxazole group. E, numerous mature oocysts in the lumen of two ducts with desquamated epithelium (double-headed arrow) $\mathrm{x} 400$ (amprolium group). F, liver with relatively normal hepatic architecture (NHA) from diclazuril treatment group $\mathrm{x} 40$. 
sulfamethoxazole treatments and those of infected-untreated control group. In our study, the artificial inoculation was induced through oral route using syringes as previous studies have shown that experimental infections induced by alternative routes such as intraperitoneal and intravenous only results in mild infections [28]. Pathogenesis and pathology following ingestion of sporulated oocysts has been described in several studies $[1,6,29]$. In the current study, only diclazuril used at $10 \mathrm{ppm}$ was able to completely resolve gross and microscopic lesions of both hepatic and intestinal coccidiosis. Hepatic and intestinal samples from rabbits treated with diclazuril recorded lowest microscopic lesion scores close to those of negative control group. Similarly, samples from diclazuril treatment group had minimal to no gross lesions indicative of its high efficacy in treating clinical coccidiosis which agree with previous studies in rabbits and in poultry $[30,31]$. Treatment with sulfachloropyrazine recorded satisfactory efficacy in ameliorating gross and microscopic lesions of coccidiosis with only minor ones that included healing fibrotic non-raised foci and fibrinous strands at the end of the study. Microscopic lesion scores organized fibrinous strands recorded by diclazuril and sulfachloropyrazine treatment groups had no significant difference ( $p>0.05$ ). Prophylactic and curative efficacy of other sulphonamides against chicken and rabbit coccidiosis have been reported [16, 32, 33]. Studies have shown that coccidiostats are best used prophylactically as they are not effective against coccidiosis once clinical signs are presented [16]. The livers and intestines from amprolium and trimethoprimsulfamethoxazole (potentiated sulphonamide) treatment groups had severe gross and microscopic lesions indicating their inability to treat clinical coccidiosis. Gross lesions in these groups were characterized by hepatomegaly, raised yellowish-white multinodular lesions, distended biliary tree filled with viscous to cheesy content, fibrinous strands on the liver surface, congested and hemorrhagic intestines with ballooned sections consistent with those described in previous studies [34, 35]. Hyperplasia and cystic enlargement of the bile duct epithelium has been reported to results in the yellowish-white nodular lesions on the liver surface seen in our study $[8,28]$. Severe microscopic lesions described for treatment groups B and F were similar to those of positive control group and have been described in other studies [34-36]. Al-Naimi et al. attributed hyperplasia of the bile duct epithelium to the multiplication of Eimerian parasites in duct epithelium, the predilection site of the parasite. Studies have shown that disruption of the continuity of bile ductile epithelium often results in formation of occysts granuloma reported in our study as the oocysts acts like foreign bodies [34-36]. Widespread fibrosis seen in livers from treatment groups B, C and F increase as the infection gets into chronic phase $[1,12,34]$. Icterus was only seen in few severely affected rabbits probably because the main product of heme breakdown in rabbits is biliverdin as opposed bilirubin [7]. Other lesions reported in our study and that have been described in previous studies include deposition of bile pigment, obstructive jaundice in hepatic parenchyma and sinusoid dilatation $[37,38,39]$. The findings of this study show that diclazuril and sulfachloropyrazine drugs can be used therapeutically against rabbit coccidiosis once clinical signs presents and have high efficacy in reversing associated lesions. Therapeutic use of amprolium and trimethoprimsulfamethoxazole is not effective in reversing coccidial lesions.

\section{Acknowledgement}

The authors acknowledge Regional Universities Forum for Capacity Building in Agriculture (RUFORUM) for funding this study and University of Nairobi for technical support. Also acknowledged are Mr. John Mukiri who assisted with histopathology work, Mr. Samuel Indeche (animal attendant) and Mr. Richard Otieno (laboratory technologist who helped with preparation of inoculum used in the study.

\section{Declarations}

Authors declare no conflict of interest

\section{Data availability}

Data used in this paper is available from:

https://data.mendeley.com/datasets/wkc39pkk24/edit

\section{References}

1. Pakandl M. Coccidia of rabbit: a review. Folia Parasitol. 2009; 56(3): 153-166.

2. Eckert J, Taylor M, Catchpole J, Licois D, Coudert, P, Bucklar H. Identification of Eimeria species and strains. Morphological characteristics of oocysts. In: Eckert J, Braun R, Shirley M, Coudert P. $1995 ; 113-116$

3. Coudert P, Licois D, Drouet-Viard F. Eimeria species and strains of rabbits. Biotechnology: Guidelines on techniques in coccidiosis research, Part. I: Eimeria and Isospora, Office for official publications of the European communities, Luxembourg. 1995;52-73.

4. Gomez-Bautista M, Rojo-Vazquez FA, Alunda JM. The effect of the hosts age on the pathology of Eimeria stiedae infection in rabbits. Vet. Parasitol. 1987; 24(1-2): 47-57.

5. Kvicerova J, Pakandl M, Hypsa V. Phylogenetic relationships among Eimeria spp. (Apicomplexa, Eimeriidae) infecting rabbits: evolutionary significance of biological and morphological features. Parasitol. 2008;135(4):443-452.

6. Patton KWH, Gorham JR, Flatt RE. Domestic Rabbits Diseases and Parasites. Pacific Northwest Extension Publication Oregon, Idaho, Washington. $2008 ; 310: 19-24$.

7. Barriga 00, Arnoni VJ. Pathophysiology of hepatic coccidiosis in rabbits. Vet. Parasitol. 1981;8(3):201-210.

8. Wang JS, Tsai SF. Prevalence and pathological study on rabbit hepatic coccidiosis in Taiwan. J. Life Sci. 1991;15(4): 240-243.

9. Al-Rukibat RK, Irizarry AR, Lacey K, Kazacos KR, Storandt ST, DeNicola DB. Impression smears of liver tissue from a rabbit. Vet. Clin. Pathol. 2001;30:57-61.

10. Toulah FH, Al-Rawi MM. Efficacy of garlic extract on hepatic coccidiosis in infected rabbits (Oryctolagus cuniculus): histological and biochemical studies. J. Egypt Soc. Parasitol. 2007;37(3):957-968.

11. Yakhchali M, Aliasghar T. Eimeriidosis and Pathological Findings in New Zealand White Rabbits. J Biol Sci. 2007;7: 1488-1491.

12. Al-Mathal EM. Hepatic Coccidiosis of the Domestic Rabbit Oryctolagus cuniculus domesticus L. in Saudi Arabia. World Journal of Zool. 2008;3(1):30-35. 
13. Abu-Akkada SS, Oda SS, Ashmawy KI. Garlic and hepatic coccidiosis: Prophylaxis or treatment? Trop Anim Health Prod. 2010;42(7):13371343.

14.Szkucik K, Renata P, Klaudiusz OS, Waldemar P. Occurrence of gastrointestinal parasites in slaughter rabbits. Parasitol Res. 2014;113(1):59-64.

15. Sivajothi S, Sudhakara-Reddy B, Rayulu VC. Intestinal coccidiosis infection in domestic rabbits. Int J Biol Res. 2014; 2(2):48-50.

16. Duszynski DW, Lee C. Chapter 10-Strategies for Management, Control, and Chemotherapy. The Biology and Identification of the Coccidia (Apicomplexa) of Rabbits of the World. 2013;253-262.

17. Vanparijs O, Hermans l, Van der Fl, Marsboom R. Efficacy of diclazuril in the prevention and cure of intestinal and hepatic coccidiosis in rabbits. Veterinary Parasitol. 1989;32(2-3):109-117.

18. Giorgi M, Niccolini A, Soldani G, Martelli F. Pharmacokinetic Study of Diclazuril in Pre-Ruminant and Ruminant Lambs. ISRA J VET MED. 2010;65(2):62-67.

19. Levine ND. Protozoan Parasites of Domestic Animals and of Man, second ed. Burgess Publishing Company, Minneapolis, Minnesota. 1973.

20.H David Chapman,John R Barta,Damer Blake,Arthur Gruber,Mark Jenkins,Nicholas C.Smith, et al. A selective review of advances in coccidiosis research. Adv Parasitol. 2013; 83:93-171.

21.US Department of Health and Human Services; Food and Drug Administration. Guidance for evaluating the effectiveness of Anticoccidial drugs in food-producing animals. Center for Veterinary Medicine, 2012

22. Joyner IP, Catchpole J, Berret S. Eimeria stiedai in rabbits: the demonstration of responses to chemotherapy. Res Vet Sci. 1983;34(1):64-67.

23. Peeters JE, Chariier G, Antoine O, Mammerick M. Clinical and pathological changes after Eimeria intestinalis infection in rabbits. Zbl. Veterinary Medicie. B. 1984;31:9-24.

24. Ryley JF, Meade R, Burst JH, Robinson TE. Methods in coccidiosis research:Separation of oocysts from faeces. Parasitol.1976,73:311-326.

25. Kiernan JA. Histological and histochemical methods. Oxford Pergamon Press.1981;201-230.

26. Carlton W, Mc Gavin MD. Thompson's Special Veterinary Pathology. 2nd Edn. Mosby, St. Louis. 1995;46-47.
27. Shackelford C, Long G, Wolf J, Okerberg C, Herbert R. Qualitative and quantitative analysis of non-neoplastic lesions in toxicology studies. Toxicol Pathol. 2002;30(1):93-96.

28. Pakes SP, Gerrity LW. Protozoal Diseases. In: The Biology of the Laboratory Rabbit, Manning, P.J., D.H. Ringler and C.E. Newcomer (Eds.). Academic Press, Inc., San Diego,Calif.1994;205-229.

29. Bhat TK, Jithendran KP, Kurade NP. Rabbit coccidiosis and its control: a review. World Rabbit Sci. 1996;4(1):37-41

30. Vereecken M, Lavazza A, De Gussem K, Chiari M, Tittarelli C, Zuffellato A, Maertens L. Activity of diclazuril against coccidiosis in growing rabbits: experimental and field experiences. World Rabbit Sci. 2012;20(4):223-230.

31.El-Banna HA, El-Bahy MM, El-Zorba HY, El-Hady M. Anticoccidial Efficacy of Drinking Water Soluble Diclazuril on Experimental and Field Coccidiosis in Broiler Chickens. J Vet Med. 2005;52:287-291.

32. Laha R, Hemaprasanth DA, Harbola PC. Comparative efficacy of sulphadimidine and combination of amprolium, sulphaquinoxalline in the control of natural coccidial infection in rabbits. INDIAN VET J. 1999;76:1013-1015.

33. Hunduma A, Kebede B. Comparative Study on the Efficacy of Amprolium and Sulfadimidine in Coccidia Infected Chickens in Debre Zeit Agricultural Research Center Poultry Farm, Bishoftu, Ethiopia. SOJ Veterinary Sciences.2016; 2(1):1-5.

34. AL- Naimi RAS, Khalaf OH, Tano SY, Al- Taee EH. Pathological study of Hepatic coccidiosis in naturally infected rabbits. QJVMS. 2012;11(1).

35. Sivajothi S, Reddy BS, Rayulu VC. Study on impression smears of hepatic coccidiosis in rabbits. J Parasit Dis. 2016;40(3):906-909.

36. Mehmoud AZ, Ibrahim MK. Granulomatous hepatitis in baldy rabbits associated with coccidial infection. Assuil. Veterinary Journal. 1989;21:55-58.

37. Darzi MM, Mirms-Kamil SA, Nashirudddullach N, Munshi ZH Pathological changes and local defense reaction occurring in spontaneous hepatic coccidiosis in rabbits (Oryctolagus cuniculus). World Rabbit Sci. 2007;15:23-28. doi:10.4995/wrs.2007.608

38. Singla LD, Juyal PD, Sandhu BS. Pathology and therapy in naturally Eimeria stiedae-infected rabbits. J Protozool Res. 2000;10:185-191.

39. Sanyal PK, Sharma SC. Clinicopathology of hepatic coccidiosis in rabbits. Indian J of Anim Sci. 1990;60:924-928. 